\title{
Teoría del perdón
}

\section{Aproximación a Jankélévitch}

¿Qué hace un teólogo metido en berenjenales filosóficos? Bueno, en realidad filosofía y teología no están tan alejadas. La filosofía es ancilla theologiae, se jactaban los escolásticos en la época en que la teología era la "ciencia superior"1. Querían señalar también, aparte de la supeditación de la filosofía, que no hay reflexión sobre Dios sin reflexión sobre la realidad; que no hay ciencia de la fe si no se somete al razonamiento lógico. Luego advinieron rivalidades intestinas, la sierva se volvió señora y la reina fue relegada a mendiga $^{2}$, hasta que la nueva señora se encontró ella misma pospuesta a la nobleza decadente y arruinada, posesora de títulos huecos, sustituida por los saberes empíricos, los nuevos ricos ${ }^{3}$. Dos ciencias y un destino. Cabría decir que son primas hermanas, tan antiguas como el pensamiento, revestidas de mitos y creadoras de culturas, buscadoras de sentido y consuelo, avaras de comprensión y compasión. Después de tantos siglos y avatares, de victorias y derrotas, de descalificaciones y solidaridades entre ellas, parece que todo sigue igual, como un veterano y cansado matrimonio.

Tal vez la respuesta sería más simple si dijera que se trata de un trabajo académico, del encargo de analizar la opinión de un filósofo, Vladimir Jankélévitch, sobre temas característicos de la religión y la teología como la culpa y el perdón. El resultado de su filosofía podría ser una fruta sana y atractiva, la visión no apologética ni insultante de las esencias de la fe, la fragancia fresca de la lógica y el sentido común envolviendo los valores cristianos.

\section{RASGOS}

Vladimir Jankélévitch, como ya delata su nombre, es de ascendencia eslava. Procede de emigrantes rusos asentados en Francia, judíos por más señas. Su padre, Samuel Jankélévitch, era médico y traductor, y fue conocido por sus

1. TOMÁs DE Aquino, Suma teológica I,1,5.

2. Es conocida la sorna de Kant: "Subsiste la duda de si la filosofía precede a su graciosa señora portando la antorcha o va tras ella sujetándole la cola del manto" (La contienda entre las facultades de filosofía y teología, Madrid 1992,11). 
versiones al francés de Hegel y Freud, además de obras rusas. Nace en 1903 en Bourges, pequeña ciudad situada en el centro geográfico de Francia. Hace sus estudios universitarios en la École Normale Supérieure de París y pronto obtuvo por oposición el título de agrégé (catedrático de instituto) en filosofía, en 1926, que proclama su dedicación investigadora y vocación docente. Aceptó la oferta de enseñar en el Institut Français de Praga, donde permaneció de 1927 a 1932, cinco años de los que siempre guardará grato recuerdo, como suele suceder con las memorias de juventud. Sus temas de enseñanza, entre otros sobre Francisco de Sales y Franz Liszt, anuncian ya sus pasiones: la mística barroca y la música clásica, de las que trufará sus obras y, en el caso de la segunda, a la que dedicará reconocidas monografías 4 . Lo mismo puede decirse del libro en que trabaja en esa época y primero que publica-Bergson, París 1931 (con una nota introductoria del estudiado alabando su trabajo)-: señala su predilección hacia el intimismo espiritual y la ética cristiana.

Presentó su trabajo de doctorado en 1933, un estudio sobre el filósofo romántico alemán Schelling5. Parecía abrir otra de sus pasiones, la filosofía alemana, pero quedó truncada, al decir de sus analistas, por la conmoción posterior de la guerra y sus asociaciones. Su tesis secundaria, de habilitación docente, retorna al marchamo moral que le interesa, el valor de la conciencia en el discurrir humano ${ }^{6}$. Después de foguearse como profesor en los lycées (institutos de secundaria) de Caen y Lyon entre 1933 y 1936, dará el salto a la enseñanza superior como profesor auxiliar en las universidades de Besançon (1936), Toulouse (1936-1937) y Lille (1938-1939), aprovechando de paso para recorrer el paisaje de su patria de norte a sur.

Y llegó la guerra, la segunda guerra mundial, catástrofe y trauma, el sello indeleble, para bien y para mal, de los intelectuales que la vivieron. Movilizado por el ejército francés desde el principio, herido a las primeras de cambio en el frente suroeste, saboreada la derrota colectiva, despojado de nacionalidad y funciones por las leyes antijudías del gobierno de Vichy, todo se sucede vertiginosamente. Retornó a Toulouse y participó activamente en la resistencia desenmascarando en escritos clandestinos la "civilización" invasora. En adelante, su inclinación a la elucubración moral quedará marcada con los tin-

3. Así, el Tractatus logico-philosophicus de Wittgenstein: "La mayor parte de las cuestiones filosóficas no son falsas, sino sinsentido" (4.003). "La totalidad de las proposiciones verdaderas es la totalidad de las ciencias naturales" (4.11).

4. Debussy et le mystère, Neuchâtel 1949; Fauré, Chopin et la nuit, Satie et le matin, París 1957; la musique et l'ineffable, París 1983.

5. L'Odysée de la conscience dans la dernière philosophie de Schelling, París 1933.

6. La mauvaise conscience, París 1933 (edición revisada y aumentada en 1966). 
tes sombríos de esta experiencia: el mal, la mentira, la muerte, temas siempre presentes en sus obras, a las que en varios casos darán título7.

En 1945, finalizada la guerra, será reintegrado a su trabajo en Lille, teniendo que esperar una plaza libre. Entretanto, viaja como conferenciante por Marruecos, Túnez y Argelia, reencontrando aquí un antiguo amor de la década previa a la guerra, con la que se casa en 1947 y tendrá una hija. Y en 1951 pasa a la Sorbona, donde ocupará ininterrumpidamente la cátedra de filosofía moral hasta su jubilación en 1978, más de veinticinco años de labor monocorde y tenaz. Uno lo imagina sentado diariamente frente a una mesa, un libro y un flexo, entre cuatro paredes, leyendo, preparando las clases o escribiendo, solazándose con el piano, consolado por el saber, la amistad y la música; la dedicación abnegada y silenciosa de estudiosos y maestros, apenas comprensible fuera de su ámbito, pero que cimientan nuestra cultura. Su esmerada rutina será apenas interrumpida por dos viajes altamente significativos, a Rusia e Israel, una especie de regreso emocional a sus orígenes.

Siempre del lado de desfavorecidos y rebeldes, apoyó la creación y defensa del Estado de Israel, a lo que permaneció fiel como idea, aun criticando errores y abusos en las formas políticos. En el hito de la revolución estudiantil del 68, destacará por su aliento a los jóvenes, que le devolvieron la simpatía recibida con abundante seguimiento de sus cursos. Tras una vida larga, gustada en sus matices agridulces, colmada por la vocación y la independencia, más allá de modas y famas, morirá en París en 1985.

La filosofía de Jankélévitch está condicionada, tanto por elección propia como por las circunstancias especiales que vivió, por la cuestión moral. La temática genérica que brota de su obra no deja de ser tradicional: la temporalidad, el conocimiento, la responsabilidad. Pero su exposición es original, tanto en su estilo personalísimo y abigarrado como en los influjos declarados de que parte. Se separa conscientemente de la última metafísica occidental (es decir, alemana y francesa), prefiriendo la tradición clásica y la espiritualidad cristiana. El resultado lleva a un filósofo relativamente conocido, lo que puede quedar bien descrito considerando que varias de sus obras están traducidas a grandes lenguas europeas (alemán, italiano, español), pero no al inglés.

En cuanto a su estilo, resulta farragoso y abrumador. Montones de palabras que se suceden sin respiro, el lector siempre al borde de perder el hilo, para alcanzar un punto y aparte tiene que jadear durante varias páginas. Del lado opuesto, el manejo de tal caudal lingüístico le hace un gran dominador del léxico y la metáfora: conoce sinónimos innumerables, crea neologismos,

7. Du mensogne, Lyon 1942; Le mal, París 1947; La mort, París 1966. 
sabe descender a comparaciones cotidianas y hermosas. Su discurso se vuelve altamente mediterráneo, esto es, pautado por el barroquismo latino, sin que pueda saberse si esto es mejor o peor -los anglosajones, al contrario, siempre fardan de concisión y rigor. Peligra de narcisismo lingüístico, estilismo puro indiferente a la sustancia; gana en hálito poético, expresividad emotiva.

El contenido es frecuentemente difícil de entender. A veces no sólo no se sabe muy bien de qué está hablando, sino que tampoco importa mucho que no se sepa: La tentación que planea es que si el lenguaje es comunicación, si alguien no logra hacerse entender ¿para qué esforzarse en entenderlo ${ }^{8}$ Para algunos, sin que se sepa muy bien el origen del prejuicio, claridad se asocia todavía a superficialidad, mientras hermetismo rima con calidad y profundidad, aunque más bien parece un retruécano estéril. Pero al revés, rechazar sin más lo que no se comprende inmediatamente es terriblemente injusto. El ser es problemático de por sí y tal marca el comienzo de la filosofía griega ${ }^{9}$. Más cercano, ¿hay alguien tan duro de seguir en sus escritos como Kierkegaard? Y sin embargo ¿ha habido quién más influyente en la filosofía de nuestro tiempo? Páginas enteras de sus obras se suceden como una carrera de obstáculos... De repente, aparece una frase que justifica todo el esfuerzo, cegadora como una revelación, sofocante como un puñetazo en el estómago ${ }^{10}$. Precisamente es Kierkegaard, juntamente con Bergson, uno de los referentes principales del pensamiento jankélévitchiano. $\mathrm{El}$ primero parece haberle contagiado aridez de lectura y fulgores geniales, aparte de la vitola existencialista; el segundo, además del estilo florido, el misticismo cristiano (desde una mirada judía) y la ética como fundamentos de la existencia humanizada.

Según Jankélévitch, lo vivido y el instante, lo que surge de la experiencia individual, y la irrepetibilidad de la existencia de cada uno, debe ser el objeto central de la filosofía. Trata de huir de la abstracción y la pura lógica, que distorsionan el saber, para allegarse al estallido vital del hombre. Su elucubración clasifica tres senderos filosóficos: las verdades necesarias teóricas del racionalismo, de un lado, y las evidencias superfluas del empirismo, de otro, de las que quiere escapar como el preso de la cárcel, derivando hacia la unicidad de la caducidad personal, lo que de verdad le interesa. En este último camino encuentra la conciencia del mal y el dolor, de lo que es imposible sustraerse, a no ser con la ignorancia o la ironía. Si inicialmente justificó la ironía como

8. "Todo lo que puede ser expresado, se puede expresar claramente" (Tractatus 4.116).

9. Para Anaximandro, el principio de todo es lo infinito, lo indeterminado. Y según Heráclito, el ser es cambio inmutable y armonía de contrarios (Los filósofos presocráticos, Madrid 1981, 89; 325ss; 347ss).

10. "La angustia es el vértigo de la libertad" (El concepto de angustia, Madrid 1940,61). "Lo contrario del pecado no es la virtud, sino la fe" (La enfermedad mortal, Madrid 1969,161). 
el consuelo distante ante la amargura de la realidad, la realidad en su contingencia radical acabó por imponérsele. No queda más remedio que asumir la intransferibilidad de la conciencia, su pena y su grandeza. La esencia humana es la temporalidad, y el instante la agudización de esa esencia. Por eso, nada hay hecho en moral, todo debe rehacerse constantemente, y a la hora de establecer un baremo de acción le serán más excelsas las "virtudes del instante" (caridad, valentía), pues brotan de las situaciones únicas individuales, que las "virtudes del hábito" (justicia, fidelidad), sostenidas por principios generales siempre por revalidar, con ser las segundas igualmente importantes ${ }^{11}$.

La simpatía hacia la moral del cristianismo, en coincidencia con sus maestros mayores, aun sin ser él creyente, le hace especialmente recomendable y cercano a nosotros. Sus libros parecen a veces una filosofía de la ética cristiana, una reflexión sin revelación que puede, sin embargo, ayudarnos a no tomar la revelación sin reflexión. Desde este contexto buscamos adentrarnos en sus ideas sobre la falta y el perdón ${ }^{12}$.

\section{EL MAL}

El mal es uno de los misterios antiguos y tercos que acosan a la humanidad. Hoy suelen condensarse los enigmas centrales del saber humano en el origen del mundo, el origen de la vida y el origen de la consciencia. Pues bien, el origen del mal sería como el cuarto enigma, que además parece abarcar a los otros tres: ¿por qué la naturaleza parece mal hecha, generadora de terremotos y diluvios, vehículo de virus y malformaciones?; ¿por qué el hombre actúa con maldad, regodeándose lúcidamente en ella? Efectivamente, antes de que Platón señalara la admiración, la estupefacción ante la realidad, como el comienzo de la filosofía ${ }^{13}$, los mitos religiosos ya elucubraban sobre la creación del mundo y del hombre y sobre la génesis de la enfermedad y la violencia14.

11. C. SMITH, Jankélévitch, Vladimir: P. Edwards (ed), The Encyclopedia of Philosophy, 4, Londres 1972, 249-250; A.E. FERNÁNDEZ, Jankélévitch: D. HuISMAN, Dictionnaire des philosophes, I, París 1984, 1335-1337; A. REINBOLD, Jankélévitch: R. D'AMAT (ed), Dictionnaire de biographie française, XVIII, París 1994, 435-436. Para más detalle sobre su obra: I. DE MonTMOLlin, La philosophie de Vladimir Jankélévitch, París 2000.

12. Para analizar el pensamiento de Jankélévitch sobre este tema nos basamos en sus libros Traité des vertus, París 1949, 543-628 (La méchanceté); La mala conciencia, México 1987 (traducción de la $2^{\mathrm{a}}$ edición francesa, 1966); y El perdón, Barcelona 1999 (original de 1967). Nuestro título es una paráfrasis de una sección de Traité des vertus 367-370: Théorie de la justice.

13. Teeteto $155 \mathrm{~d}$.

14. Gn 1-3: la creación es expresión del poder divino; el hombre, interlocutor de Dios; el mal, consecuencia del pecado. Paralelos temáticos son el poema babilónico Enuma elish y las recopilaciones míticas de Hesíodo Teogonía y Trabajos y días: el mundo es una divini- 
Es también muy antigua la subdivisión del mal en cuanto surgido de la naturaleza, mal físico, o provocado por la libertad del hombre, mal moral. El pensamiento socrático entendía el mal humano como ignorancia, consecuencia de su naturaleza limitada, por tanto, reducible al mal físico; su idea resuena en Leibniz, que también se apoya en último término en el mal físico: puesto que lo creado, en cuanto distinto de Dios, es necesariamente limitado, imperfecto, el mal es inherente a la naturaleza, lo que llamó mal metafísico ${ }^{15}$. Lo contrario aparece en san Agustín, que lo reconduce todo al mal moral: todo mal es a fin de cuentas producto de la perversión humana, puesto que el mal físico es justo castigo divino por el pecado, tanto el original como el personal16. La solución está lejos de vislumbrarse. Nuestras modernas discusiones sobre si en las desviaciones y crímenes pesan más la libertad individual o la educación ambiental son una subdivisión del mal moral como último fundamento, al que se contrapone paralelamente la teoría de la predisposición genética o compulsión instintiva, versión actualizada del mal físico.

Jankélévitch prosigue esta discusión eterna al estudiar en sus obras el mal y la maldad, al internarse en este "corazón de las tinieblas", que dijera el clásico, "el horror"17, presupuesto para entender luego la posibilidad y necesidad del perdón. Da la impresión de que la solución del dilema le parece en principio insignificante, en último análisis sobre todo imposible. El caso es que la existencia humana es siempre incerteza, inseguridad. El hombre, "criatura anfibia, mixta de cuerpo y alma, está consagrado por la maldición de la alternativa a la impureza y a la orgía de la confusión"18.

\section{La absurdidad}

Inicialmente, Jankélévitch parece insertarse en la línea leibniziana. "Esta angina de pecho, esta falta de aliento que se llama imperfección define primeramente la existencia en tanto que existencia y no sólo impura continuación, sino limitación y finitud creatural. Ser es también no ser más que lo que uno es -éste o aquél- y no ser otra cosa. Tal es la versión exotérica y negativa

\footnotetext{
dad vencida por otro dios dominante; el hombre ha sido creado para el servicio a los dioses; el mal proviene del orgullo humano contra los dioses. Una línea distinta sobre el mal será la de la religiosidad dualista (de raíz mazdeísta y continuidad gnóstica), que lo recentra en una divinidad mala, descargando de responsabilidad al hombre (S. AGUSTín, Confesiones, 4,15,26).

15. Menón 77b-78b; Ensayos de teodicea 1,21.

16. El libre albedrío $1,1.35 ; 3,53 \mathrm{~s}$.

17. J. CONRAD, El corazón de las tinieblas, Madrid 1976, 139.

18. Traité 543 .
} 
de todo enunciado positivo"19. Sin embargo, hay cierta diferencia de matiz. Si para Leibniz la imperfección constitutiva fundamenta la comprensión última de la negatividad de las cosas, para Jankélévitch es sólo el contexto de la explicación principal que se pueda dar, el trasfondo sobre el que destaca el nudo de la cuestión.

Se percibe en su consideración de los valores. Un valor es tal en cuanto colma una necesidad humana, en cuanto supone una utilidad saludable (valeo, tener salud). En ese sentido, remarca nuestro autor, todos los valores son iguales. Pero resulta que los valores son muchas veces inconciliables o al menos discordantes. Así que en todo caso se impone elegir, esto es, echar mano de unos desechando los otros. Hay que aceptar excluir y renunciar si se quiere utilizar y disfrutar, no sirve el "de todo un poco". Hay que tener el coraje del sacrificio. Mas si los valores son todos iguales, si todos valen, pero hay que eliminar necesariamente unos al escoger otros, ya estamos maniobrando en cierto absurdo. Es la absurdidad del sacrificio: descartar para tener. Y sin embargo, es el único marco que posibilita una vida saludable. Naturalmente, existe un valor primordial, fundamento y referencia de todos, subsuelo que les sirve de alimento, cuya principalidad ontológica es evidente, por tanto, indemostrable y arracional, que es el amor a la persona, base de cualquier acción ${ }^{20}$.

Esto encierra una enseñanza preciosa para nuestro tiempo. Los cristianos estamos acostumbrados a una claridad excesiva de nuestros valores, así como a su imposición universal, consecuencia de estirar demasiado el concepto de revelación. Quince siglos (o al menos diez) de ordeno y mando tienen que dejar secuelas. Hoy día, perdido sin remedio el poder de la Iglesia, ésta deberá proponer su mensaje desde el ejemplo y la sugestión. Además, la desorientación social sobre criterios éticos se muestra receptiva a propuestas razonadas y no autoritarias. Pues bien, desde el sentido común, supuesta la intangibilidad de la persona, podemos estar de acuerdo en que todos los valores son iguales. "Cada cual es dueño de hacer lo que quiera si no hace mal a nadie", como solemos comentar. No hay una jerarquía absoluta de valores, cada uno debe construírsela, pero asumiendo que aceptar unos valores conlleva eliminar otros. Así, por ejemplo, a un hombre puede encantarle la vida de familia, la intimidad con una mujer, unos hijos a los que educar y ver crecer; pero también pueden sorberle el seso las aventuras amorosas, la intensidad emocional continua, que toda mujer sea la primera. Sin embargo, estos dos tipos de valores son incompatibles, ninguna esposa de hoy acepta a un

19. Traité 545.

20. Traité 552. 
donjuan impenitente, si se prefiere el placer de la variedad no se tendrá la cercanía cotidiana de los hijos. Hay que renunciar para poseer, hay que admitir el sacrificio. Pero esto es lo que no quiere entender nuestra sociedad, hedonista hasta el ridículo, lo exige todo en todo momento, en una auténtica regresión infantil.

Volviendo al tema, según Jankélévitch los valores traslucen cierta absurdidad saludable. Se podría seguir la línea optimista, el adjetivo de su diagnóstico, aceptar la limitación existencial que constantemente se nos impone como un modo de concentración en lo escogido. Que en fútbol el balón tenga que entrar, bajo determinadas condiciones, entre los tres palos de la portería para ser gol no es una imperfección, sino las reglas del juego, lo que canaliza e intensifica su búsqueda, lo que otorga el orgullo de la superación (o el dinero) una vez conseguido. Pero es imposible eliminar la línea pesimista, el sustantivo de la frase, la absurdidad. Ésta estalla en la vida del hombre como a un soldado infortunado la bomba entre las manos. No es sólo la absurdidad de la renuncia, al fin y al cabo susceptible de ser integrada como concreción para la dicha, sino que aquélla se muestra síntoma de una calamidad mayor: "la muerte sella la profunda absurdidad de la existencia". El absurdo es lo que prevalece, los valores son derrotados por la muerte. No se trata, pues, de una imperfección de fondo, derivada de la limitación de lo creado, que hay que asumir y así poder alcanzar cierta autorrealización. Para la existencia humana la muerte es la imperfección absoluta, la vida se le muestra como una vía inviable, un proyecto ilusionante condenado al fracaso. "El amor es necesariamente desgraciado, y desgraciado no por un fracaso accidental, sino desgraciado por una imposibilidad central y constitucional". Así que el mayor de los valores no hace sino ahondarnos en la desdicha. En conclusión, "todos los problemas que no sean la muerte son pseudoproblemas; todos los verdaderos problemas son formas del problema mortal, que es el problema por excelencia, es decir, el misterio de los misterios". Y además, resulta un problema insoluble, eterno, "la enfermedad de la existencia es una enfermedad incurable"21. La vida es dura, como suele decirse, al final siempre acaba matándote.

\section{El escándalo}

No obstante el tenebrismo anterior, ni la imperfección ni la muerte son auténticamente el mal. El mal verdadero y fuerte es la maldad. Jankélévitch distingue en francés (lo que tiene correlación perfecta en español) entre mau-

21. Traité 559-561. 
vais (malo) y méchant (malvado). La palabra "malo" es ambigua, significa imperfecto (materialmente) y malvado (moralmente), mientras "malvado" es ciertamente inequívoca, expresando sólo la idea moral de "muy malo". Esto es lo que quiere decir al hablar del mal auténtico. Y la maldad se nutre de la intención. "Malum ethicum, el mal intencionado, la perversión del corazón", he ahí realmente el mal22. La falta, la culpa, el pecado, como quiera llamársele, no es una imperfección constitutiva, dada desde siempre con las cosas, sino un mal que los hombres inventan, del que son enteramente responsables. Algo así como la guerra, que no puede existir sino por voluntad expresa del hombre. La imperfección, el dolor, la muerte, son males necesarios, ontológicos. Pero la maldad, la culpa, es un mal contingente, dependiente de la libertad humana, podría evitarse.

Jankélévitch rechaza el optimismo socrático, y en general del helenismo, de que nadie quiere el mal conscientemente, de que quien se decide por el mal en realidad lo está tomando por un bien, que el pecado es más bien un lapsus. Según él, una libertad que sólo puede elegir el bien no es una libertad completa, por tanto, no es libertad. La solución del mal, en esta teoría, sería el conocimiento racional, la educación que explicita nuestras posibilidades. Pero el mal consciente, la malevolencia, querer el mal sabiendo que es un mal, tiene un peso histórico tan abrumador (en el siglo anterior, Auschwitz como símbolo) que no puede juzgarse el socratismo sino de ingenuo ${ }^{23}$.

Desecha igualmente la opinión platónica, que interpreta el mal como consecuencia de la contaminación que el cuerpo realiza en el alma, los sentidos como coacción irracional al espíritu. Su raíz está en el orfismo, la síntesis griega de la religiosidad dualista oriental, actualizado luego por estoicos, gnósticos y neoplatónicos, y reargüido a través del pecado original cristiano. El mal es más que nada mancha, alma patricia en cuerpo plebeyo, el predominio de los instintos, "el vicio es un vértigo del cuerpo"24. Aquí, la solución del mal pasará por mimar la esencia humana, el alma, y controlar y castigar al inductor, el cuerpo. Es una salida irreal, cada hombre no son dos, sino uno, por más que pueda disociar y admirar sus potencialidades anímicas respecto de la fragilidad somática. Demonizar los apetitos sensibles es autodestructivo. En este caso, los cristianos sabemos muy bien de qué se habla, puesto que el cristianismo ha heredado y contribuido a grabar y expandir esta idea: el cuerpo es el origen de las pasiones que atormentan la placidez del alma, el pecado

22. Traité 561.

23. Traité 563s; Conciencia 98; Perdón 83ss.91ss.

24. Traité 568. "El pecado original es el a priori culpable que envenena de antemano nuestras intenciones más puras, que hace que nuestras virtudes parezcan hacer muecas" (Conciencia 126). 
original la causa de que el cuerpo haya quedado corrompido, el remedio del pecado es la penitencia corporal.

Prefiere el resquebrajamiento aristotélico de la ecuación socrática: hacer el mal por ignorancia no siempre es hacer el mal involuntariamente, pues no toda ignorancia es excusable. Si la práctica crea el hábito, los actos malos continuados crean la maldad personal, de modo que uno se hace culpable de su carácter. El actuante humano, por tanto, en su elección y disposición, es señor de su obrar y puede ser injusto a sabiendas. Aristóteles compromete en la responsabilidad del querer, en la construcción humana del propio destino ${ }^{25}$. Solamente así, el hombre adquiere dignidad moral, esto es, valoración legítima de sí, de lo que es y de lo que deviene, de su hacerse a sí mismo.

Llegados a este punto, hemos retornado al embrollo sempiterno, si la intención maliciosa proviene sólo de la responsabilidad propia o de sus condicionamientos, prevalece el mal físico o moral, el huevo o la gallina. La opción socrático-platónica es la misma a fin de cuentas, lo deriva todo hacia una causación por error o tentación sensorial. Pero según nuestro autor, la malevolencia no puede reducirse a la imperfección metempírica, o eliminaremos la esencia libre del ser humano. Los cristianos, dice, parecen confirmar inconscientemente dicha línea al ensimismarse en un pecado original que hace culpables por naturaleza, antes de cometer culpa. Sin embargo, tal es una contradicción, no hay más pecado que el personal, el que procede de la intención. Es imposible ignorar el peso terrible del pecado consciente, el escándalo, "el mal artificial y arbitrario que el hombre añade de su cosecha al mal constitutivo de existir, la absurdidad. (...) Por si no fuera bastante la desdicha del ser, el hombre asume la desdicha del hacer" 26 . Las confrontaciones humanas remachan lo que las catástrofes naturales ahorran. Y en esto no nos vale eludir la responsabilidad: si no podemos nada contra el mal metafísico, lo podemos todo contra el pecado. "Nuestro ser es una prueba de la absurdidad, pero nuestro hacer es el principio del escándalo"27. De manera que el escándalo es una confirmación de la absurdidad, lo que añade al mal genérico, el marco de lo creado, males concretos, que a su vez contribuyen a multiplicar el mal inicial. El escándalo agrava el absurdo.

Según se haga predominar el absurdo o el escándalo, el mal nos resultará excusable o inexcusable, y tal es el error, contar sólo con una cara de la moneda. Una verdad a medias es considerar al hombre absolutamente responsable de su pecado, comienzo puro del mal sin mayor base ontológica. La otra

\footnotetext{
25. Traité 565-567; Conciencia 99.

26. Traité 579.

27. Traité 584.
} 
semiverdad será juzgarle sólo víctima, motor movido, diluyendo la libertad en el fatalismo. Juntando ambas llegaremos a la idea correcta, podremos deducir que "el mal mismo es la posibilidad permanente del pecado" 28 , es decir, la situación falible de la libertad. El escándalo está siempre condicionado e influido, pero no determinado o forzado, por la absurdidad. Podríamos decir, avezados a la política española, que el mal moral tiene autonomía, aunque no independencia, respecto del mal físico. La imperfección metafísica y la responsabilidad ética conforman las coordenadas de la acción humana en el mundo. El hombre padece el mal, pero es autor de la maldad; es víctima cómplice de la negatividad.

Jankélévitch concluye que el pecado de los pecados es la falta de amor, del mismo modo que el amor es el valor de los valores. La ausencia de amor no es una carencia, sino una intención, una culpa, la malicia continuada que convierte la negligencia e ignorancia en maldad. Y la intensidad del pecado, el pecado mortal, será directamente proporcional a la conciencia del bien omitido, a querer el mal fríamente, a la mala voluntad. Esta falta continuada y crónica, actitud más que acto, se convierte en vicio, el pecado frecuentativo de malevolencia, el odio. La mala voluntad es la que hace existir el mal al desearlo, proyecta su valoración en la cosa odiada. Es decir, no existe lo odioso en sí, sino que es fabricado por la disposición perversa de la voluntad; no es lo odioso lo que explica el odio, sino el odio quien crea lo odioso. La mala voluntad no es la voluntad de cualquier mal, así en abstracto, sino la voluntad de mal hacia alguien. Y una voluntad de mal radical: el malvado simplemente desea que el objeto de su odio no exista. Precisamente esto deviene una situación desesperada e insostenible para el malvado, "negando al otro como consanguíneo, consustancial, confraternal, congenital, es a sí mismo a quien niega"29.

\section{EL PERDÓN}

Contra el mal físico nos precavemos con la ciencia y la medicina, si bien la absurdidad es finalmente invencible. ¿Y cuál es la respuesta adecuada al mal moral? ¿La justicia o el perdón? ¿el castigo que repara el desorden causado o la indulgencia que libera de la espiral de odio y venganza?

28. Traité 588. También Conciencia 129; Perdón 64.

29. Traité 611. Una concejal constitucionalista de una ciudad del País Vasco comentaba en una entrevista que le estomagaban fuertemente los nacionalistas violentos, que vivía con miedo; pero que ellos debían de estar todavía peor: odiaban tanto a los no nacionalistas que tenían que corroerse internamente por verles al lado, por tener que soportar su existencia (El País Semanal, 22.X.2000,18ss). 


\section{La mala conciencia}

"Todo el mundo tiene, en general, buena conciencia. Nadie se reconoce faltas ni se estima culpable en lo más mínimo, esto es de sobra conocido; cada quien está convencido de su derecho y de la injusticia de los demás hacia él"30. Este diagnóstico parecería tomado de algún ensayo sobre la posmodernidad, el nihilismo axiológico o los jóvenes apáticos de la segunda mitad del siglo XX. Jankélévitch, sin embargo, lo ha visto como tendencia común del hombre y la sociedad, presente en todo tiempo y lugar, teorizado ya con Aristóteles, para quien el placer es un propósito evidente de conducta, el impulso básico de toda criatura que afirma su existencia. Pues bien, la felicidad, el motor de la ética clásica, no difiere del placer más que en racionalidad, en ordenamiento lógico. El goce se consume en la espontaneidad e inmediatez mientras la dicha se organiza para la duración y el largo plazo. La conciencia moral, la capacidad de discernir el bien y el mal, presiona hacia la felicidad, que por eso es el bien, y repele el dolor, el mal. Es natural, por tanto, que el hombre rechace la mala conciencia, pues el remordimiento es dolor. Sin embargo, con ello ha quedado dicho que el remordimiento forma parte de la conciencia, es más, "el remordimiento es la conciencia en su forma más aguda, (...) una inflamación de la conciencia", pues en él se manifiesta de modo particular el espíritu, su apertura para trascender la mecánica instintiva. La conciencia es, pues, también la capacidad de percibir el dolor moral, algo que todo hombre posee, aunque intente de ordinario adormecerla. Suele suceder que la mala conciencia "llega siempre tarde, (...) no nos dice lo que hay que hacer, sino lo que habría habido que hacer" 31.

La mala conciencia es en realidad el perdón a uno mismo. El remordimiento, el dolor de la conciencia, es la única posibilidad de purificación del mal realizado. A esta conclusión llega tras disquisiciones de fondo triste sobre la temporalidad. El tiempo humano es la existencia humana, irreversible e irrepetible, único y por eso mismo excepcionalmente valioso, hermoso y dramático a la vez. "La vida de un hombre, encerrada entre nacimiento y muerte, ¿no es en el océano infinito de lo eterno como una especie de gran instante?"32. La religión, la moral y la filosofía, en buena medida, ponen lo mejor de sí mismas para dar respuestas y consolar, pero no llegan más que a posibilidades imposibles. El estoicismo trivializa lo irreemplazable, la excepcionalidad trágica de la existencia, como si la mismidad de cada uno no fuera no

30. Conciencia 7.

31. Conciencia 38-41.

32. Conciencia 75. 
fuera única e incomparable; es decir, nos inserta en el cosmos dejándonos engranados como un pequeño fragmento del todo, nuestro sufrimiento no es más que un detalle de un orden superior, el individuo no puede creerse el centro del universo. El cristianismo, por su parte, es más piadoso que la indiferencia estoica, quiere hablar al corazón más que a la razón, pero pospone la solución al futuro, lo centra todo en una esperanza escatológica compensadora, que por eso mismo no compensa nada la laceración presente. "La conceptualización naturista desdibuja mi tragedia privada en la inmortal juventud de las primaveras y de las metempsicosis, mientras que la promesa religiosa escamotea mi pena en los cielos de oro de la atanasia"33.

La irreversibilidad del tiempo es en sí misma dolor, y una mala acción, en ese marco, implica una cristalización insoportable del dolor, el sufrimiento inconcebible de lo irreparable, pues una reparación contradice la irreversibilidad del devenir. El remordimiento será la aguda conciencia de una culpa que ya no es posible contrarrestar. A no ser que la reparación sea el remordimiento mismo, la desolación por la imposible marcha atrás de una falta, el arrepentimiento. "El pecado mismo -es decir, el mal en sí- para curarse engendra el dolor de la mala conciencia, es decir, el mal de la desdicha personal"34.

Jankélévitch utiliza términos cristianos, aunque sin darle enteramente ese sentido, para mostrar la catarsis que brota de la mala conciencia. Primero la penitencia, un ritual expiatorio y reparador provocado por uno mismo, que sigue al arrepentimiento como el actuar al ser, que quiere contrapesar la mala acción de algún modo y expresarlo externamente. Luego la conversión, la disposición seria de no repetir el mal, una vez sentido hondamente como tal. A este punto, en la conversión queda ya esbozada la redención, la recuperación del culpable. Todo ha comenzado con esa especie de "gracia que es el dolor puro del arrepentimiento"35. Quiere decir que el punto de partida del remordimiento no se explica muy bien, es causa sui, es como si brotara de la nada, nace por sí mismo en el interior de la conciencia. Y así, el dolor del arrepentimiento debela la falta: penitencia, conversión y recuperación personales van a ser su secuencia lógica. La curación de la culpa no puede ser sólo el olvido, como si nada hubiera pasado, lo que sería ocultar el pecado en lugar de sanarlo, profundizarlo al enterrarlo vivo en el inconsciente. Ni tampoco la restitución, impracticable por la irreversibilidad del tiempo, una especie de Sísifo voluntarioso. Sólo la mala conciencia, en su desgarro purificador, puede dar valor y sentido a un pasado culpable. Esto evoca la distinción escolástica entre

33. Conciencia 71. $622)$.

34. Conciencia 108. "El remordimiento es el pecado transfigurado en virtud" (Traité

35. Conciencia 110. 
atrición y contrición para resaltar la regeneración inmediata cumplida en lo segundo, en el dolor sincero por el reconocimiento del mal cometido. "El remordimiento es el perdón instantáneo, gratuito, inmerecido, que hace curables nuestras faltas y que prepara la remisión" 36 .

\section{Deber perdonar}

¿Y qué decir del perdón a los demás, es decir, el perdón desde el pưnto de vista del ofendido, de las víctimas, de los derrotados por la maldad? En estos casos, el perdón resulta algo terriblemente paradójico, muchas veces "excepcionalmente difícil", y sin embargo, siempre "un deber"37. El deber de perdonar es algo deducible de todo lo que se viene diciendo.

Primeramente, el perdón es una vertiente del amor, como el reverso de la medalla, pues si amas perdonas. El perdón es "ese imperceptible parpadeo de la caridad"38. Si el amor es el valor fundamental, que sostiene todos los demás, como hemos dicho, el perdón formará parte del humus de la vida sana. Podríamos preguntarnos todavía por qué Jankélévitch considera el amor como el valor central, y de un modo tan tajante que obvia su explicación. Los cristianos nos sentimos de acuerdo con esto sin más, pues el amor es nuestra enseñanza más cara, la esencia del cristianismo: el mandamiento mayor (Mc 12,28-31), el mandamiento nuevo (Jn 13,34), lo primero y lo último (1Cor 13). Podremos colegirlo desde la fe en Dios Padre -sólo lo sentiremos verdaderamente como Padre si nos comportamos como hermanos-o desde la convicción de que si Dios es amor no se le experimenta más que amando (1Jn 4,8), pero sobre todo es algo que creemos. Mas un filósofo se apoya en razones. Nuestro autor supone la vida como el haber principal, la ipsidad personal no puede renovarse nunca, el individuo es inefable e irreemplazable, único "en toda la historia, y que ocurre no una vez al mes como la luna llena, ni una vez al año como las solemnidades de los aniversarios, ni una vez por siglo como los cometas, sino una vez en toda la eternidad. (...) La vida es la más preciosa de todas las ocasiones" 39 . En realidad, la vida es lo único que tenemos cada uno, punto de partida de todo lo demás, y así el amor a los otros es el amor a la vida, particularmente a la semejante, la base de cualquier otra cosa. El perdón, por lo tanto, tendrá las mismas características que el amor.

36. Conciencia 117.

37. Perdón $7 \mathrm{~s}$.

38. Perdón 11.

39. Conciencia 75 . 
Es gratuito, desinteresado, un valor en sí, no necesita nada a cambio. Dicho poéticamente, “¿cómo el amor que ama lo no amable y, por consiguiente, no lo debe al valor de su objeto, cómo este amor no va a ser fecundo y manifiesto entre todos los amores? ¿cómo no va a ser sinónimo de libertad?"40. En su incondicionalidad reside su eficacia. Jankélévitch destaca filosóficamente un dato común de la moderna exégesis bíblica: Jesús no pide primeramente conversión y luego ofrece el perdón, siguiendo el esquema del profetismo paleotestamentario, sino justamente al revés, primero perdona, lo que luego genera fuerzas para levantarse. El perdón absuelve porque sí, como el amor ama, se fundamenta en sí mismo, constituye su propia causa. Por eso el perdón es indestructible, autosuficiente como lo son todos los valores, firmes como una roca e indiferentes a nuestros cabezazos en su contra. En este sentido, el perdón es ilimitado en todas las direcciones, temporal y espacialmente, cualitativa y cuantitativamente, "perdona todo a todos y no se entretiene en distinguir las culpas graves de las culpas leves. (...) En su infatigable paciencia, su inquebrantable confianza, su inagotable generosidad, está a prueba de los crímenes más inexpiables" 41 . Esto recuerda al himno paulino a la caridad como una gota a otra gota. Todas las faltas son perdonables, aunque no todas sean excusables o comprensibles, la grandeza del perdón no se mide por la gravedad de la ofensa, sino por el espíritu de quien perdona. Todo esto no significa que el perdón sea fácil, todo lo contrario, pues supone tragarse el amor propio, el honor o la fama que veneran nuestros clásicos y la mentalidad popular. Al implicar una renuncia a la compensación, el perdón conlleva buenas dosis de sacrificio.

Es instantáneo, espontáneo como el temperamento, una forma de entender la vida. Se parece en esto a la felicidad, que no es una cosa, sino que reside en un talante, un modo de ser. "Jesús exhorta al humillado y al abofeteado a tender la otra mejilla no veinte años después del bofetón, no después de pensárselo bien, después de haber reposado la afrenta y procurado olvidar, sino acto seguido" 42 . No hay razones concretas para perdonar, sino más bien al revés, se perdona porque no hay razones, pues si las hubiera cabría más la excusa que el perdón. El perdón puro, como forma del carácter personal, sin contraprestaciones, aunque no sea exactamente posible, aunque tan solo norme el ideal que nunca se alcanza, dibuja el horizonte difuso de la dicha. Con esto no se dice que el perdón sea olvido, como ya se dijo respecto de la mala conciencia, pues tal devendría sólo un rencor mal curado, presto a reaparecer en cualquier momento. Sería como confiar en el tiempo, que lo borra

40. Traité 625 .

41. Perdón 131.133; también, Conciencia 122. 
todo, como la arena removida por el viento tapa las huellas más hendidas; pero el mismo viento -las circunstancias o el inconsciente inesperados-, puede descubrir las marcas rellenadas. Aunque parezca una broma de la crueldad, "para perdonar hay que acordarse. El rencor es la condición curiosamente contradictoria del perdón; y por el contrario, el olvido lo vuelve inútil"43.

Es relacional, está siempre referido a alguien, es tan intencional como el pecado, es un ejercicio de la voluntad. En este sentido, puede suponer un heroísmo, a veces tremendo, que se llegue a perdonar al torturador tras haber sido torturado por él. Esto resulta inconcebible, insoportable, cuando sucede "algo terrible, más allá del perdón"44. Y sin embargo, sólo así es real, llevado a cabo por alguien hacia alguien que le ha herido. El perdón en abstracto es sólo una hipótesis por confirmar. En el supuesto socrático de que no hay maldad, sino tan sólo error, tampoco sería necesario el perdón, únicamente comprender el fallo y excusar. Jankélévitch se permite bromas macabras para dejar sentado esto: Spinoza superviviente de Auschwitz no hubiera podido decir que comprender es perdonar, se habría dado de bruces con lo incomprensible; y los cristianos, si consideran ciegos a los judíos, ya les han disculpado, y si malévolos, "¿no han bastado veinte siglos de rencor implacable para que la religión del perdón perdone a quienes acusa?"45. La cuestión discurre al revés: perdonar es comprender, es decir, entender la capacidad de mal común al hombre, la maldición de la libertad, en la que todos estamos involucrados. Perdonar es tocar el misterio de la vida y la libertad.

El perdón supone la justicia, aunque la supera. La primera parte de la frase no está muy desarrollada por nuestro autor, tal vez porque le resulta obvio y prefiere resaltar lo segundo. La justicia penal y reparadora, por legítima que le parezca, no deja de ser un castigo, una represalia socialmente aceptada, algo inferior al perdón. Esta justicia es demasiado expiatoria, devuelve mal por mal, mientras el perdón, al contrario, devuelve bien por mal. El perdón pide renunciar a la tentación vindicativa, sobrepasar la justicia, aunque ésta sea necesaria para la armonía social, para frenar el mal y desbaratar en lo posible sus efectos. Por eso, "para el acreedor, el perdón es la renuncia a un derecho" 46 . Una culpa que perdonar al culpable es primeramente un rencor que desbancar en uno mismo. Pero después hay que intentar recuperar al malvado para el bien sin transigir con su maldad, no puede tole-

42. Perdón 50.

43. Perdón 79.

44. G. ORwELL, 1984, Barcelona 1979, 43.

45. Perdón 94.102.

46. Perdón 171. 
rarse una malevolencia desfachatada. Por tanto, la justicia está incluida en el amor y el perdón, el amor supera la justicia después de suponerla.

Este perdón tan magnánimo, este amor al malvado no es amor a su maldad, lo que sería una perversidad morbosa, sino amor del hombre mismo en su versión más difícil, en la negrura de su libertad, de lo que todos participamos. Es la aceptación del hombre en su esencia ambivalente, esencia común al ser humano, aceptación de la propia similitud ontológica con el culpable. Pero no se ama al culpable a causa de su culpa, sino a pesar de su culpa. En este mismo sentido se expresa la tradición cristiana, que habla de detestar el pecado pero amar al pecador. El apoyo racional que ha ofrecido Jankélévitch es igualmente cristiano, aunque perdido en nuestro inconsciente colectivo: todos podemos ser igualmente pecadores aunque no lo seamos de hecho. ¿Acaso no simboliza eso el mito del pecado original, una solidaridad negativa de esencia? ¿No es igualmente el mensaje indirecto de las antítesis (Mt $5,21 \mathrm{ss}$ ), que nadie está libre del rencor, del mal deseo, de la mentira, origen de los mayores crímenes? Además, da una segunda razón, asimismo impensadamente cristiana: "No se trata de amar al malvado en cuanto malvado, sino de amar al malvado en cuanto que es un pobre hombre" 47 . El malvado no solamente es un hombre, partícipe de la condición común, sino también un pobre hombre, que revela la miseria de la realidad humana en su pecado. Alguien que no ha entendido la sustancia de la vida, el amor, no es más que un desdichado que merece compasión, por mal que haga, aunque haya que pararle los pies de todos modos ${ }^{48}$.

El perdón así diseccionado por Jankélévitch es asumible, punto a punto, por los cristianos. Aunque no se basa en la revelación, sino en razones éticas, en el sentido clásico, las movidas por el impulso de una vida feliz -parece inscribirse en la corriente eudemológica de la filosofía griega, continuada más tarde por Spinoza-, sin embargo no está nada alejado de su contenido. La fe cristiana alienta también a la felicidad, signo e impulso de la salvación o felicidad completa. E igualmente, para los cristianos el perdón es una de sus notas características, un gemelo del amor. Y partiendo del amor, la esencia del cristianismo, se sigue que el perdón es también constante (setenta veces siete en matemáticas son cuatrocientas noventa, pero en el evangelio significa siempre, Mt 18,21s), universal respecto personas y ofensas (el prójimo es todo

47. Traité 624ss; Perdón 192.

48. Estando en un hospital, en ese ambiente tan típico en que se mezclan desordenadamente dolor, angustia, cansancio y esperanza, veíamos en la sala de espera enfermos y parientes el telediario informando de un atentando etarra. Uno de los pacientes, de pie, con su bata y portasuero, comentó absorto: "Con lo que cuesta cuidar la vida, y que esos desgracia'os la quiten en un segundo". 
hombre que uno encuentra, Lc 10,29ss; todos los pecados son perdonables, Mc 3,28 ) e incondicional (como Dios "hace salir su sol sobre buenos y malos, y llover sobre justos e injustos", Mt 5,45).

Respecto a la incondicionalidad, hay una puntualización destacada por Jankélévitch, que inicialmente parece contradecir a la fe, pero que en último análisis se descubre coincidente. El perdón es infinito, dice, no hay culpa lo bastante grave que no pueda ser perdonada. Sin embargo, hay una condición sin la cual el perdón no es posible. Nos quedamos expectantes, extrañados, ¿pero no se ha pasado el libro entero diciendo...? "La primera condición, sin la cual el perdón carecería de sentido, es el desamparo y el insomnio y la derelicción del culpable; y aunque no corresponda al perdonador plantear esta condición, esta condición representa aquello sin lo cual la problemática del perdón resulta una simple payasada" 49 . El arrepentimiento del malhechor, su remordimiento, es una premisa elemental, lo único que valida el perdón. Podríamos decir que para perdonar a otro es imprescindible que el otro se perdone a sí mismo.

La lógica subyacente es estricta, aunque Jankélévitch no la explicite. La libertad malintencionada es el mal propiamente dicho, el mal entre los males. La maldad está en la intención, y mientras tal mala intención persista, ¿cómo es posible la connivencia del bien, el perdón? Es como la cuadratura del círculo. También el evangelio habla del imperdonable pecado contra el Espíritu Santo (Mc 3,19), la mala voluntad para la tradición cristiana, que reconoce que Dios no puede salvar sin la aquiescencia de cada cual ${ }^{50}$. El perdón a otro es una manera de ser y pensar, una esperanza de cambio, el deseo de un mundo mejor, lo que queda cínicamente pisoteado y suspendido si no hay remordimiento del culpable. Confraternizar con los verdugos, desestimar los valores y a los mártires, es traición más que perdón, una indecencia hacia las víctimas. Si el amor es el valor más duradero, eterno, la indiferencia a las vejaciones contra ese valor será la culpa más imperdonable. El perdón y la maldad libran así una lucha sin tregua. "Continuamente, la infatigable, la inagotable bondad del perdón salva el insalvable muro de la maldad y de continuo el muro resurge delante de la bondad. (...) El amor es más fuerte que el mal y el mal más fuerte que el amor, ¡son más fuertes el uno que el otro! El espíritu humano no podría llegar más allá. (...) Por ello el perdón es fuerte como la maldad, pero no más fuerte que ella" 51 . Como el pensamiento frente a la muerte, el perdón es la vida frente al mal, resulta al tiempo omnipotente e im-

49. Perdón 210s.

50. S. Agustín, Sermones 169,13.

51. Perdón 218-220. 
potente. Es un enfrentamiento insoluble, pero al menos queda el consuelo de la fuerza del perdón, que no es inferior a ninguna.

Es tal la excelsitud, sentido y empuje del perdón, que Jankélévitch se embelesa. "Si hiciera falta escoger entre la existencia e inexistencia de la maldad, tal vez sería mejor optar por su existencia, a fin de que el amor conociese antes o después la oportunidad maravillosa del perdón" 52 . Esto suena un poco excesivo para el sentido común, pero bien pensado ni más ni menos que el dicho evangélico de amar a los enemigos u ofrecer la mejilla derecha a quien te golpee en la izquierda. No es sólo que el mal únicamente puede vencerse desde el bien, que es el mensaje cristiano, mientras Jankélévitch lo ha dejado en empate; es también que el amor no se entiende en toda su fuerza más que desde su contrario, igual que no puede apreciarse enteramente lo inestimable de la vida más que desde la conciencia de la muerte, o la belleza de la luz y el color sino en la desazón de la oscuridad. También para él, aquí reside la esencia del cristianismo. "Cristo habría muerto por nada si su muerte no hubiera servido más que para despilfarrar en pura pérdida y fijar en fetiches ridículos [sagrado corazón, reliquias, santos, etc] la preciosa necesidad de ternura, las capacidades de afecto tan restringidas, los flacos recursos de generosidad de que el corazón humano dispone" 53 .

\section{EPÍLOGO}

Después de todo este recorrido, queda claro que la filosofía no es sólo el arte de decir lo que todo el mundo sabe de modo que nadie lo entienda, como reza el chiste estudiantil. Es también indagar en las emociones profundas del hombre, ordenarlas. Es pensar los límites del ser, hablar de lo enigmático, interrogar el misterio de la existencia. Es una necesidad humana, ayuda a vivir conscientemente, a palpar mínimamente la felicidad, imposible sin resaltar la propia esencia racional. "El que no piensa es como que no vive", oí decir sin ánimo docente, como de pasada, a un misionero perdido en el ajetreo de su labor en la Amazonía, necesitado de meditación.

El perdón es una evidencia cristiana, casi interiorizada genéticamente tras siglos de predicación. Pero la cotidianidad práctica lo contradice permanentemente, incluso lo imposibilita como cosa de lelos o pánfilos, de los que el mal se va a aprovechar, empeorando a fin de cuentas las cosas. Es necesario razonarlo, asimilarlo como convicción íntima a prueba de decepciones. $\mathrm{La}$

52. Traité 628.

53. Traité 624. 
aportación de Jankélévitch, como la de otros filósofos en otros temas, resulta impagable. También para los cristianos, demasiado engreídos por una revelación que parecen pensar controlar.

Podemos discordar con Jankélévitch en su diagnosis de la absurdidad como última palabra, creemos que la muerte no es el final. Pero tendremos que asentir a su consideración de la responsabilidad humana en toda maldad, muchas veces mitigada por la presión de circunstancias adversas, pero en modo alguno suprimida. La pretensión constante de inocencia atrofia la responsabilidad, infantiliza, enquista en el despropósito. Si no admitimos culpa por el fracaso matrimonial o por el abandono de la opción sacerdotal, si nos escudamos en inmadureces juveniles o incapacidades transitorias, ¿cuándo pensamos ser adultos? Podrá haber oportunidad de recomenzar la vida, partir de cero, pase lo que pase, pero no a costa de sacudirse los errores como la caspa de las hombreras. Si no reconocemos las faltas personales, graves o leves, ¿cómo podemos arrepentirnos?, ¿cómo vamos a mejorar? Si somos principescamente inocentes, ¿hasta donde llegaremos a hundirnos? Estaremos despreciando la caricia firme y transformadora del perdón, propio o ajeno.

Persas y romanos crucificaban como sistema de poder, en la Edad Media y Renacimiento europeos se decapitaba, empalaba, descoyuntaba y quemaba al por mayor; con la modernidad ilustrada y los adelantos técnicos se ampliaron las muertes y refinaron las torturas, que con la aldea global contemporánea se universalizaron geográficamente, aplicaron en masa y adelantaron antropológicamente (niños que aprenden a matar)... La maldad es fiel compañera de la historia. Omnipresente y tozuda, a pesar de todo sorprendente, de cualquier manera deprimente. Sólo tenemos el consuelo del perdón. Es difícil decir esto a las víctimas, pero el perdón, como la esperanza y la justicia, es un modo de mirar el cielo azul, una defensa contra el mal.

TOMÁs MARCOS MARTíneZ Estudio Teológico Agustiniano

Valladolid 